\title{
Influence of sodium chloride on wine yeast fermentation performance
}

\author{
This article was published in the following Dove Press journal: \\ International Journal of Wine Research \\ 24 June 2010 \\ Number of times this article has been viewed
}

\author{
Stilianos Logothetis' \\ Elias T Nerantzis ${ }^{2}$ \\ Anna Gioulioti ${ }^{3}$ \\ Tasos Kanelis ${ }^{2}$ \\ Tataridis Panagiotis ${ }^{2}$ \\ Graeme Walker' \\ 'University of Abertay Dundee, \\ School of Contemporary Sciences, \\ Dundee, Scotland; ${ }^{2}$ TEl of Athens \\ Department of Oenology and \\ Spirit Technology, Biotechnology \\ and Industrial Fermentations Lab \\ Agiou Spiridonos, Athens, Greece; \\ ${ }^{3}$ Ampeloiniki SA Industrial Park \\ Thermi, Thessaloniki, Greece
}

\begin{abstract}
This paper concerns research into the influence of salt (sodium chloride) on growth, viability and fermentation performance in a winemaking strain of the yeast, Saccharomyces cerevisiae. Experimental fermentations were conducted in both laboratory-scale and industrial-scale experiments. Preculturing yeasts in elevated levels of sodium chloride, or salt "preconditioning" led to improved fermentation performance. This was manifest by preconditioned yeasts having an improved capability to ferment high-sugar containing media with increased cell viability and with elevated levels of produced ethanol. Salt-preconditioning most likely influenced the stress-tolerance of yeasts by inducing the synthesis of key metabolites such as trehalose and glycerol. These compounds may act to improve cells' ability to withstand osmostress and ethanol toxicity during fermentations of grape must. Industrial-scale trials using salt-preconditioned yeasts verified the benefit of this novel physiological cell engineering approach to practical winemaking fermentations.
\end{abstract}

Keywords: salt, preconditioning, fermentation performance, Saccharomyces cerevisiae, wine

\section{Introduction}

Modern winemaking has significant demands concerning product consistency and quality and is driving winemakers to make the right choices at every stage of production from grape to glass. It is important to emphasize the importance of yeast genetics and physiology in winemaking since yeast activities during must fermentation impacts directly on: yeast growth, alcohol productivity, stress-tolerance, sugar utilization, volatile (higher alcohol and ester) compound production and off-flavor (carbonyl and sulphur compounds) development. ${ }^{1-3}$ Various strains of Saccharomyces cerevisiae are available as starter cultures to supply distinctive sensory attributes to wine ${ }^{4,5}$ and yeast strain choice can affect the varietal character of aromatically distinctive grape cultivars by influencing the liberation of bound grape congeners. Winemakers rely on fermentations being rapid and producing predictable flavor and aroma characteristics in the finished wine. Wine yeast genetics and cell physiology are therefore of paramount importance in this regard. Desired $S$. cerevisiae characteristics for winemaking include: osmotolerance, relative insensitivity to high acidity, and acceptance of low oxygen concentrations.

Osmotic stress (osmostress) represents an environmental insult to yeasts and triggers a series of biological responses as cells strive to maintain viability and cell cycle progress. Many studies of osmostress in laboratory strains of $S$. cerevisiae have focused on transcriptional activation, changes in protein synthesis, DNA damage and DNA recovery, gene expression and apoptotic phenomena. ${ }^{6,7}$ Studies of osmostress in wine yeasts caused by high sugar have been reported, ${ }^{8}$ but there are few reports specifically investigating effects induced by elevated sodium chloride $(\mathrm{NaCl})$ levels. ${ }^{9,10}$ We therefore aimed to
Correspondence: Stilianos Logothetis Megalou Alexandrou, 17I2I Nea Smirni, Athens, Greece

Tel +00302I 09324734

Fax +0030 2109324734

Email stilianos.logothetis@gmail.com 
further our understanding of cell physiology and fermentation performance in wine yeasts exposed to salt-induced osmotic stress conditions. We focused on the evaluation of salt effects on the wine yeast, S. cerevisiae strain VIN 13 (Anchor Ltd, Capetown, South Africa), and subsequent fermentation performance in both laboratory and industrial experiments formulas of salts. Industrial wine fermentations were performed to evaluate the effects of salt preculturing (or preconditioning) of cells regarding alcohol productivity, glycerol production and sugar utilization. Our working hypothesis was that salt stress conditions energized specific genes to enable yeast cells to survive under subsequent stressful conditions during grape must fermentations.

\section{Materials and methods Laboratory scale experiments} Yeasts cultures and growth conditions

A yeast strain of $S$. cerevisiae (VIN 13) used for experimental fermentations was kindly donated by Anchor Ltd. Yeast cells were grown on defined medium containing (per liter deionized water): $100 \mathrm{~g}$ D-glucose, $1 \mathrm{~g} \mathrm{~K} 2 \mathrm{HPO} 4,1 \mathrm{~g} \mathrm{~K} 2 \mathrm{H} 2 \mathrm{PO} 4,0.2 \mathrm{~g}$ ZnSO4, 0.2 g MgSO4, 2 g yeast extract and $2 \mathrm{~g} \mathrm{NH} 4 \mathrm{SO} 4$. All the media components were purchased from Sigma Chemical Company (Sigma-Aldrich, St Louis, MO, USA).

\section{Inoculum preparation}

Cell rehydration: $1 \mathrm{~g}$ dry weight of yeast was diluted in $100 \mathrm{~mL}$ of deionized water in an Erlenmeyer flask of $250 \mathrm{~mL}$ volume at $30-35^{\circ} \mathrm{C}$, for $30 \mathrm{~min}$. Inocula for experimental fermentations were prepared as follows: after 48 hours of preculturing, $10 \mathrm{~mL}$ was collected and centrifuged at $5000 \mathrm{rpm}$ for $15 \mathrm{~min}$. Cells were resuspended in deionized water and recentrifuged. This was repeated twice prior to determination of total cell number and cell viability in the final washed inoculum. To inoculate $250 \mathrm{~mL}$ of substrate, $5 \times 10^{5}$ of living cells were used as an inoculum.

\section{Fermentation media preparation}

The medium for experimental laboratory fermentations consisted of the following: $200 \mathrm{~g} / \mathrm{L}$ glucose, $1 \mathrm{~g} / \mathrm{L}$ K2HPO4, $1 \mathrm{~g} / \mathrm{L} \mathrm{K} 2 \mathrm{H} 2 \mathrm{PO} 4,0.2 \mathrm{~g} / \mathrm{L} \mathrm{ZnSO} 4,0.2 \mathrm{~g} / \mathrm{L} \mathrm{MgSO} 4,2 \mathrm{~g} / \mathrm{L}$ yeast extract and $2 \mathrm{~g} / \mathrm{L}(\mathrm{NH} 4)_{2} \mathrm{SO} 4$. Mineral components and the glucose were sterilized separately at $120^{\circ} \mathrm{C}$, and 2 atm pressure for $20 \mathrm{~min}$. The $\mathrm{pH}$ was adjusted using $1 \mathrm{~N} \mathrm{HCl}$ solution. For salt stress induction experiments, medium contained $\mathrm{NaCl}$ (commercial $\mathrm{NaCl}$ was used) and the total volume for the medium for each fermentation medium was $250 \mathrm{~mL}$. Batch fermentations were carried out in $300 \mathrm{~mL}$ volume
Erlenmeyer flasks containing $250 \mathrm{~mL}$ of growth medium without shaking at $25^{\circ} \mathrm{C}$. After inoculation $1 \mathrm{~mL}$ was periodically taken direct from each flask in order to monitor the differences between stressed and unstressed yeast cells with respect to yeast population growth and cell viability.

\section{Yeast growth and viability determination}

Yeast cell number was determined using a hemocytometer (Thoma type) and yeast cell viability using the methylene blue method. ${ }^{11}$ One mL of sample medium was taken and diluted in $9 \mathrm{~mL}$ of deionized water. One $\mathrm{mL}$ of this solution was dissolved with $1 \mathrm{~mL}$ of $10 \% \mathrm{v} / \mathrm{v}$ methylene blue solution and left for $10 \mathrm{~min}$. Aliquots of $1 \mu \mathrm{L}$ were placed on the hemocytometer by using a Pasteur pipette. The hemocytometer was then microscopically observed by an optical microscope (Olympus model CHK2-F-GS microscope, Shinjuku, Tokyo, Japan). Yeast cell viability was calculated and expressed as follows:

$$
\text { Viability }(\%)=a / n \times 100
$$

Where, number of metabolically active cells and n, total cell number. Since cellular viability was determined immediately after hyperosmotic treatments, in vivo staining with methylene blue, which is rapid and accurate, was used.

\section{Glucose measurement}

Glucose was determined using the dinitrosalicylic acid (DNS) method $^{12}$ for lab scale fermentations.

\section{Ethanol measurement}

Ethanol was determined using an enzymatic kit from Boehringer Manheim/R-Biopharm, Darmstadt, Germany, Cat. No. 10176290035.

\section{Glycerol measurement}

Glycerol was determined using an enzymatic kit from Boehringer Manheim/R-Biopharm, Darmstadt, Germany, Cat. No. 0148270.

\section{Industrial scale fermentations}

For industrial scale fermentation experiments, a quantity of $10000 \mathrm{~L}$ of must from Chardonnay grape varieties was used from a 2005 harvest in Greece. Grapes cultivated from the same area of an altitude of 550 meters came from the same two hectares of vineyard located at the area of Mendenitsa, Fthiotida, Central Greece. Cultivation methods were the same for each year and the grape harvest took place at the same period. A prefermentation procedure of cryo-extraction was made at the same temperature and for precisely 12 hours. For the inoculum, $1250 \mathrm{~g}$ of dry yeast was diluted in $50 \mathrm{~L}$ 
water containing $500 \mathrm{~g}$ of sucrose at $35^{\circ} \mathrm{C}$. Two inocula were made for each tank: one contained $\mathrm{NaCl}(6 \% \mathrm{w} / \mathrm{v}$ of commercial $\mathrm{NaCl}$ in crystal form was used) for yeast osmoadaptation (or "salt-preconditioning") and the other without $\mathrm{NaCl}$. After 24 hours inocula were added to each tank. Each fermentation was conducted in stainless steel tanks, $5000 \mathrm{~L}$ in volume. Fermentation temperature was maintained at $10^{\circ} \mathrm{C}$ for Chardonnay fermentations. The analysis of industrial scale fermentations was made by FOSS Oenos Wine $\mathrm{Scan}^{\text {тм }}$ (FOSS, Copenhagen, Denmark).

\section{Statistical analyses}

Firstly, the average of the three values separately was calculated. Secondly, the average value of the three average values was calculated. The column of these results was analyzed with the statistical programme called BioStat Plus 2008 version 5.3.0.6 by AnalySoft Corp (Brachnell, UK) using the Basic Describe Statistics package.

\section{Results and discussion}

The effect of $\mathrm{NaCl}$ on growth and viability of the industrial yeast strain, $S$. cerevisiae VIN 13.

It is known that when $\mathrm{NaCl}$ is added to a growth medium containing yeast cells the intracellular concentration of $\mathrm{Na}+$ increases, and this has a negative effect on yeast growth and viability. ${ }^{13}$ Similarly, ${ }^{14}$ studies have shown that treatment of
S. cerevisiae cells with $\mathrm{KCl}$ up to $6 \%$ caused a great loss of viability. A gradual increase of $\mathrm{NaCl}$ in a growth medium containing yeast cells can cause a cell growth arrest depending on the $\mathrm{NaCl}$ concentration. ${ }^{15}$ Experiments have shown that the leavening ability of baker's yeast decreases dramatically during cultivation in media containing $\mathrm{NaCl}$ concentrations between 0 and $3 \% .{ }^{16}$ Prior research ${ }^{17}$ showed that the greatest loss in cell viability was caused under hyperosmotic conditions between 0 and 1 OSM, (OSM = Osmolarity $=5.85 \%$ $\mathrm{NaCl}$ w/v). Interestingly, between 1 and 4 OSM, the loss of viability was smaller. ${ }^{17}$ Comparative studies on the effect of osmotic stress in S. cerevisiae and non-Saccharomyces strains have shown that non-Saccharomyces strains displayed higher salt tolerance. ${ }^{18}$ In general, previous studies have revealed that osmotic stress and especially $\mathrm{NaCl}$-induced stress, caused growth arrest and negatively affected the viability of yeast cells.

In the following laboratory-scale series of experiments (Figures 1 to 3 ) the effects of salt from concentrations ranging from $0 \%-10 \% \mathrm{NaCl} \mathrm{w} / \mathrm{v}$ on wine yeast $(S$. cerevisiae VIN 13 strain) cell growth and viability were investigated. The findings indicate that $\mathrm{NaCl}$ caused a growth arrest in this strain and the difference between untreated cells and the cells which were treated under the highest salt-induced osmotic stress $(10 \% \mathrm{NaCl} w / \mathrm{v})$ was around $2.5 \times 10^{6}$ cells. When $\mathrm{NaCl}$ concentration increased the total cell number concomitantly

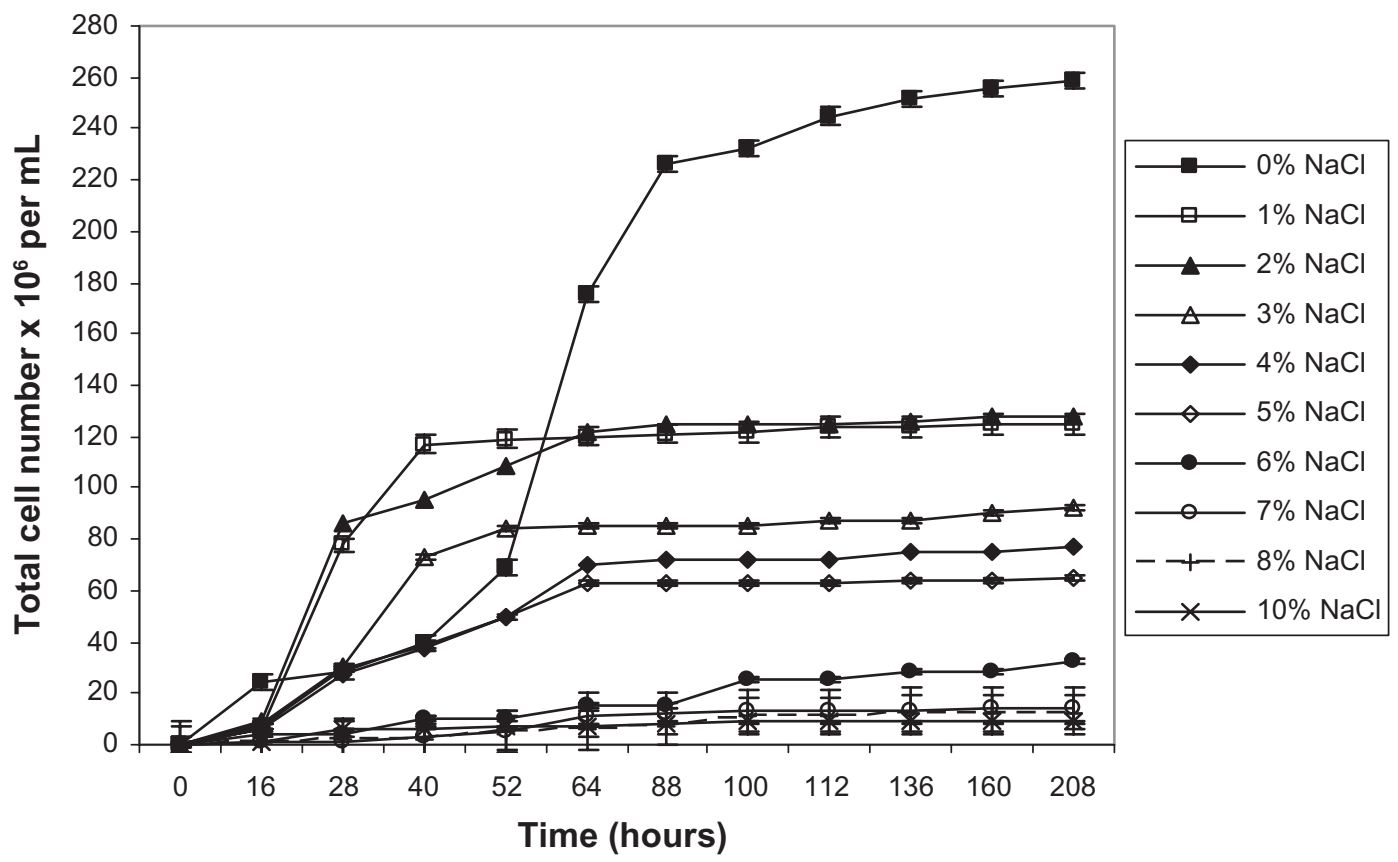

Figure I Influence of salt-induced osmotic stress $(0 \%-10 \% \mathrm{NaCl})$ on yeast cell growth. Saccharomyces cerevisiae (strain VIN I3, Anchor Ltd, Capetown, South Africa) was grown on a glucose-based ( $200 \mathrm{~g} / \mathrm{L} \mathrm{D}$-glucose) defined medium, without shaking at $25^{\circ} \mathrm{C}$. Yeast cell growth was determined using a hemocytometer at the intervals shown. The standard error was between 1.30 and $8.28 \%$. 


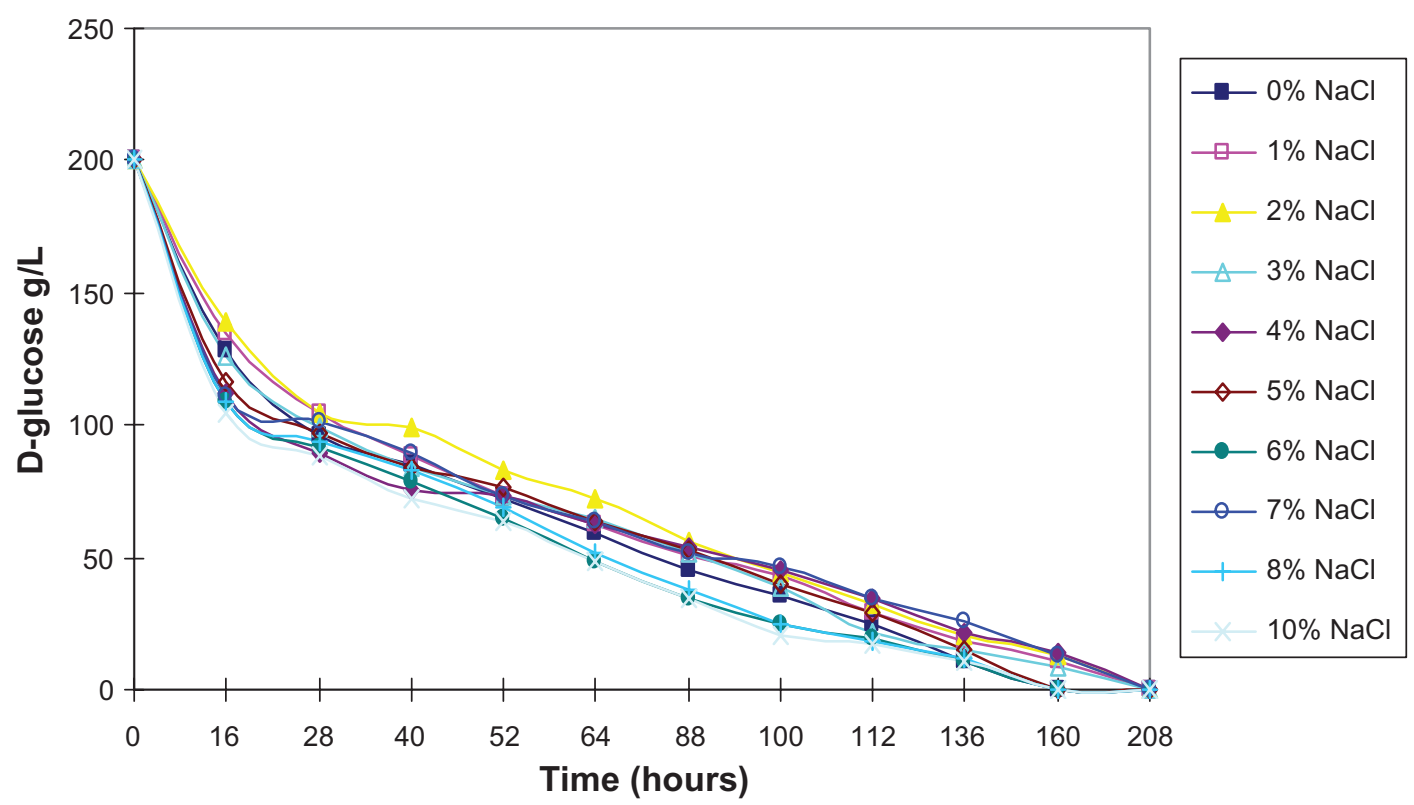

Figure 2 Influence of salt-induced osmotic stress $(0 \%-10 \%$ w/v NaCl) on sugar consumption. Saccharomyces cerevisiae (strain VIN I3, Anchor Ltd, Capetown, South Africa) was grown on a glucose-based $\left(200 \mathrm{~g} / \mathrm{L} \mathrm{D}\right.$-glucose) defined medium, without shaking at $25^{\circ} \mathrm{C}$ containing $200 \mathrm{~g} / \mathrm{L}$ of $\mathrm{D}$-glucose. Sugar consumption was determined by the DNS method and the standard error was between 1.09 and $3.03 \%$.

decreased. The results shown in Figure 1 are in accordance with previously published findings ${ }^{6,19}$ in that $\mathrm{NaCl}$-induced osmotic stress causes a growth arrest for yeasts cells. When osmotic stress $(\mathrm{NaCl}$ concentration) is gradually increased, a decrease in yeast growth and the total cell number during time occurred. However, regarding viability, cells treated under higher osmotic shock conditions $(>5 \% \mathrm{w} / \mathrm{v} \mathrm{NaCl})$ resulted in cells possessing a higher viability at the end of the fermentation (Figure 3). If we compare Figures 1 and 3 showing yeast growth and yeast viability, it can be seen that yeast cells exposed to higher concentrations of $\mathrm{NaCl}$ have the lowest growth but the highest viability compared with cells which were treated under lower osmotic shock conditions. Previous research supports the concept that when $S$. cerevisiae cells are exposed to high concentrations of $\mathrm{NaCl}$, they show reduced viability resulting in cells acquiring tolerance against a severe salt shock (up to $1.4 \mathrm{M} \mathrm{NaCl}=8.19 \% \mathrm{NaCl}$ w/v) following a previous treatment with $0.7 \mathrm{M} \mathrm{NaCl}(4.09 \% \mathrm{NaCl}$ $\mathrm{W} / \mathrm{v}) .{ }^{20}$ Overall, previous reports describe the osmotic stress of yeast cells for no more than a few hours, but in the current research cells were treated for at least 228 hours (Figure 1) during the fermentation process. In Figure 3 the results are contrary to published findings, especially concerning yeast cell viability, presumably due to the longer period of adaptation to the saline environment.

Previous studies have reported that some agents, like $\mathrm{NaCl}$, play an important role in minimizing or inhibiting the fermentation process, specifically with regard to glucose utilization for the production of yeast biomass. ${ }^{21}$ Much earlier studies regarding this subject have been performed. For example, in the 1920 s, studies concerned with the fermentability of yeasts during cereal wort fermentation under different $\mathrm{NaCl}$ concentrations showed that the fermentative ability of yeast increased when preconditioned with $5 \% \mathrm{w} / \mathrm{v}$ $\mathrm{NaCl}$, but for higher concentrations, a gradual reduction of fermentative efficiency was reported. ${ }^{22}$ In the present work, it is clearly shown that for concentrations from 1 to $10 \% \mathrm{w} / \mathrm{v}$ $\mathrm{NaCl}$, no difference in glucose utilization occurred and the fermentability of the yeast cells was approximately the same for all salt concentrations tested (Figure 2).

From Figure 1 it can be seen that higher $\mathrm{NaCl}$ concentrations have a suppressive effect on yeast growth. The difference between total cell number of stressed cells and nonstressed cells is almost $2.5 \times 10^{6}$ cells $/ \mathrm{mL}$ after 208 hours.

Regarding cell viability, high resistance of the cells to salt stress conditions were observed following a range of $\mathrm{NaCl}$ treatments. Results showed that after 64 hours of fermentation, yeast viability for untreated cells and for low $\mathrm{NaCl}$ concentrations started to decrease but the viability for stressed cells remained high. After a period of 208 hours, viability for untreated cells fell to around 50\% and cells under highest osmotic conditions retained high viability. This may be due to the fact that under osmotic stress, and especially under salinity conditions, an increase in cellular electrolytes and a decrease in cellular water potential occurred. ${ }^{23,24}$ Consequently, rapid efflux of water, cytoskeletal collapse, intracellular damage 


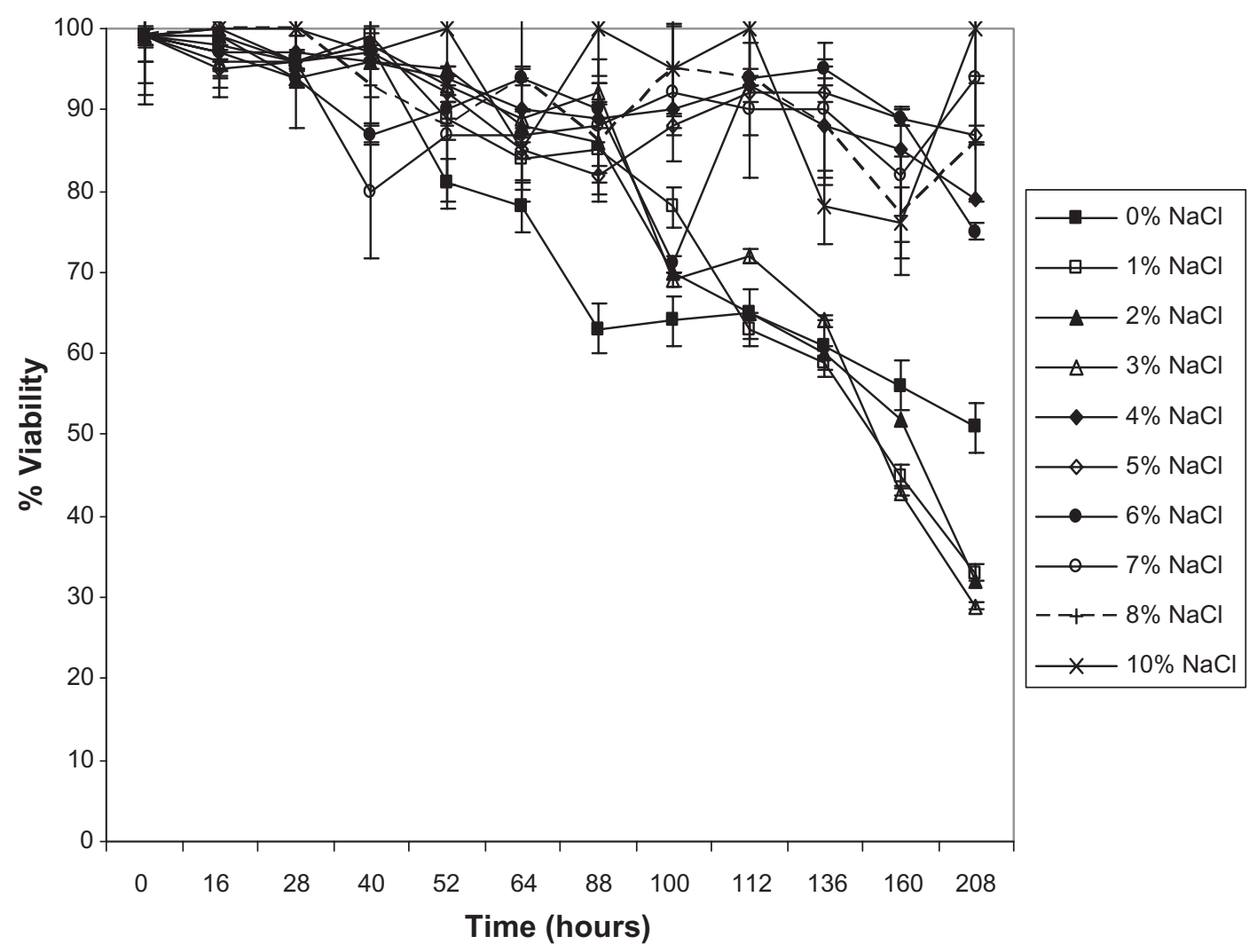

Figure 3 Influence of salt-induced osmotic stress (0\%-10\% w/v NaCl) on yeast cell viability. Saccharomyces cerevisiae (strain VIN I3, Anchor Ltd, Capetown, South Africa) was grown on a glucose-based defined medium, without shaking at $25^{\circ} \mathrm{C}$. Yeast cell viability was determined by methylene blue staining using a hemocytometer at the intervals shown and the standard error was between 1.75 and $5.28 \%$.

and growth arrest, are typical phenomena following saline stress. Adaptation to these conditions by yeast cells include: retainment of turgor, polarized cytoskeleton, cellular damage repair, and resumption of growth. It is conceivable that the response is controlled by the high-osmolarity glycerol (HOG) mitogen-activated protein (MAP) kinase pathway. ${ }^{6}$ It has been reported that accumulation of glycerol, which is the main compatible solute that cells produce intracellularly to adapt to the differential extra and intracellular osmotic pressure, is strongly affected by growth temperature and causes the over expression of GPD1 and FPS1 genes, which encode the glycerol transport facilitator and glycerol-3-phosphate dehydrogenase. ${ }^{25}$ The temperature $\left(24^{\circ} \mathrm{C}\right)$ in these published studies was very close to the temperature that this experiment was running.

It has been reported that osmotic stress caused by $0.3 \mathrm{M}(1.75 \% \mathrm{NaCl} \mathrm{w} / \mathrm{v}) \mathrm{NaCl}$ and for a time period of 1 hour may prolong the life span of yeasts. ${ }^{26}$ The relationship between temperature and osmotic stress regarding osmotic tolerance of cells and viability has previously been reported. Under osmotic pressure of $49.2 \mathrm{MPa}$ cell viability was close to $94 \%$ at a temperature of $23^{\circ} \mathrm{C}$, but under higher osmotic pressure of $99 \mathrm{MPa}$ the viability decreased dramatically to $25 \% .{ }^{27}$ It was reported that under the same conditions of high osmotic pressure of $99 \mathrm{MPa}$, but at a temperature of $5^{\circ} \mathrm{C}$, cell viability remained at a high level of $81 \%$.

\section{Fermentation performance in industrial scale experiments}

During this part of the research, experiments were conducted on an industrial (Georgakopoulos Estate Winery) scale using the same four industrial yeast strains as per lab-based fermentations. The strain $S$. cerevisiae VIN 13 was employed for the 2005 winemaking season using must from Chardonnay variety grapes. For this 2005 grape harvest we used $\mathrm{NaCl}$ preconditioned and unconditioned yeast cells for inoculation of $5000 \mathrm{~L}$ stainless steel tanks. Preconditioning of the cells was conducted by treating cells with $6 \% \mathrm{w} / \mathrm{v} \mathrm{NaCl}$ for 16 hours in the inoculum volume $(200 \mathrm{~L})$. This concentration of $\mathrm{NaCl}$ was chosen following promising data from the lab scale experiments (see Figures 1 and 3 ) that showed better yeast viability and maximum growth compared with higher salt conditions. 


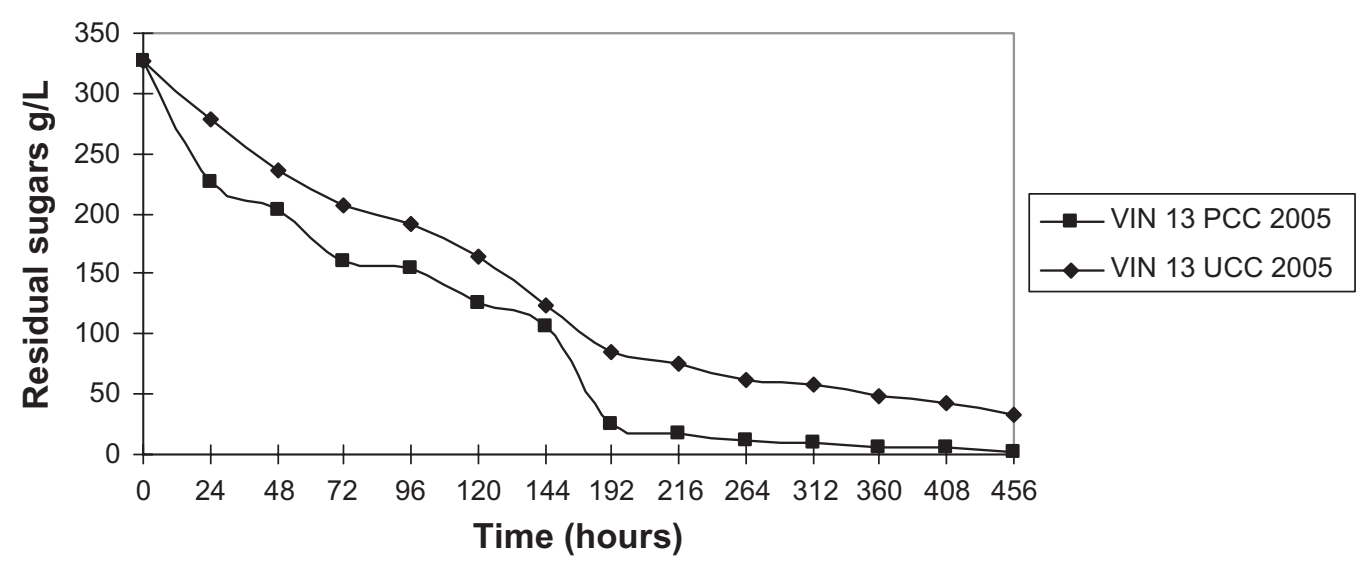

Figure 4 Sugar consumption by salt-preconditioned and unconditioned wine yeast during fermentation of 2005 Chardonnay must. Standard error was 2.3 . Fermentations were conducted with preconditioned and unconditioned yeasts (strain VIN I3, Anchor Ltd, Capetown, South Africa) using $6 \% \mathrm{NaCl}$ and growing cells for 24 hours prior to inoculation of $5000 \mathrm{~L}$ stainless steel tanks containing Chardonnay must. Must was clarified by pectynolitic enzymes and filtered before inoculation.

For all winemaking years, results were compared with the "standard" given by the yeast-producing companies (Anchor and Martin Vialate) for each yeast strain. We aimed to show that preconditioning under salt stress conditions for cells had a positive effect regarding: alcohol productivity, fermentation yield (regarding sugar consumption) and sugar and temperature stress tolerance. The latter conditions involved cells withstanding fermentation temperatures for every year of $9-10^{\circ} \mathrm{C}$ and sugar concentrations higher than $300 \mathrm{~g} / \mathrm{L}$.

Figures 4-6 demonstrate the fermentative behavior of the VIN 13 yeast strain regarding sugar consumption, alcohol production and glycerol production. The results compare the behavior of the same strain with cells which were preconditioned under salt stress conditions of $6 \% \mathrm{NaCl}$ $\mathrm{w} / \mathrm{v}$ for 24 hours before inoculation and those that were not preconditioned. From Figure 4 the pattern of sugar consumption for both cases was the same but residual sugars at the end of the fermentation the difference was around $30 \mathrm{~g} / \mathrm{L}$ of D-glucose. Additionally, alcohol productivity and glycerol production were affected by salt-preconditioning. For example, the alcohol content at the end of the fermentations differed by $3 \% \mathrm{v} / \mathrm{v}$ and the glycerol concentration by $10 \mathrm{~g} / \mathrm{L}$. These results show that salt-preconditioned yeast cells are able to ferment high sugar concentrations with low residual sugars at the end of the fermentation and can produce higher yields of alcohol in comparison with the un-preconditioned cells. The higher levels of glycerol produced following preconditioning is significant in winemaking, especially for white wines since glycerol is related with the textural (mouthfeel, body) characteristics of such wines.

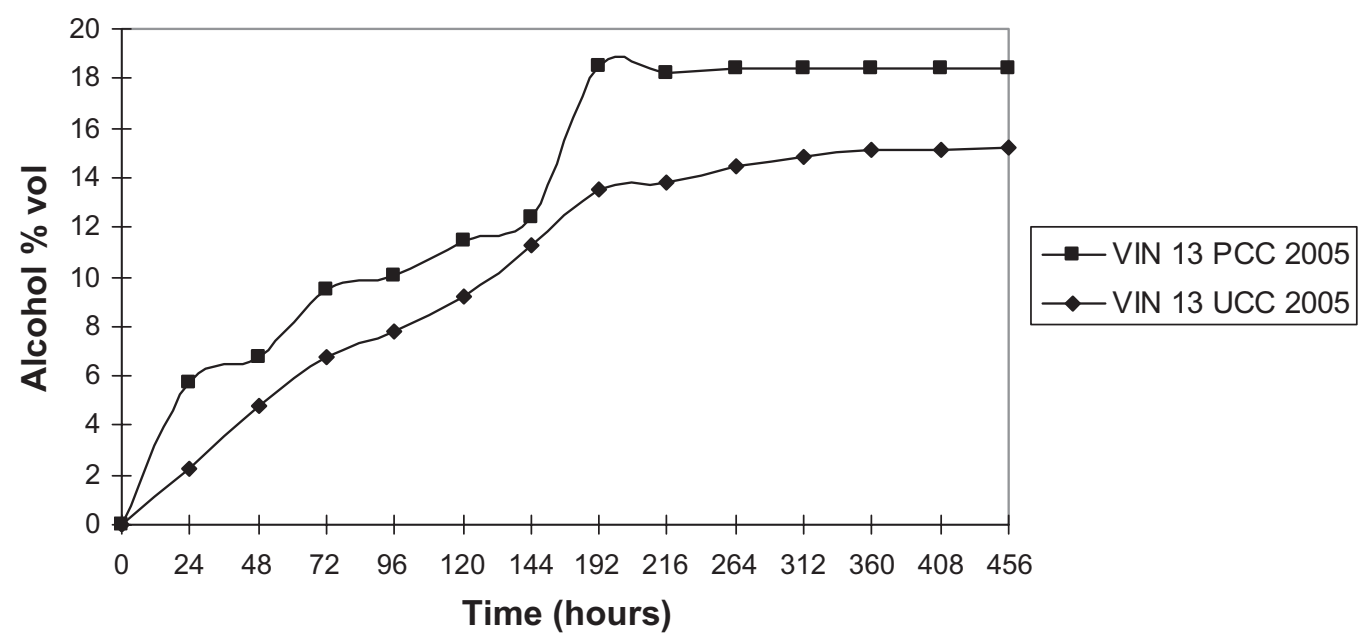

Figure 5 Alcohol production by salt-preconditioned and unconditioned wine yeast during fermentation of 2005 Chardonnay must. Standard error was I.23. Fermentations were conducted with preconditioned and unconditioned yeasts (strain VIN I3, Anchor Ltd, Capetown, South Africa) using $6 \% \mathrm{NaCl}$ and growing cells for 24 hours prior to inoculation of $5000 \mathrm{~L}$ stainless steel tanks containing Chardonnay must. Must was clarified by pectynolitic enzymes and filtered before inoculation. 


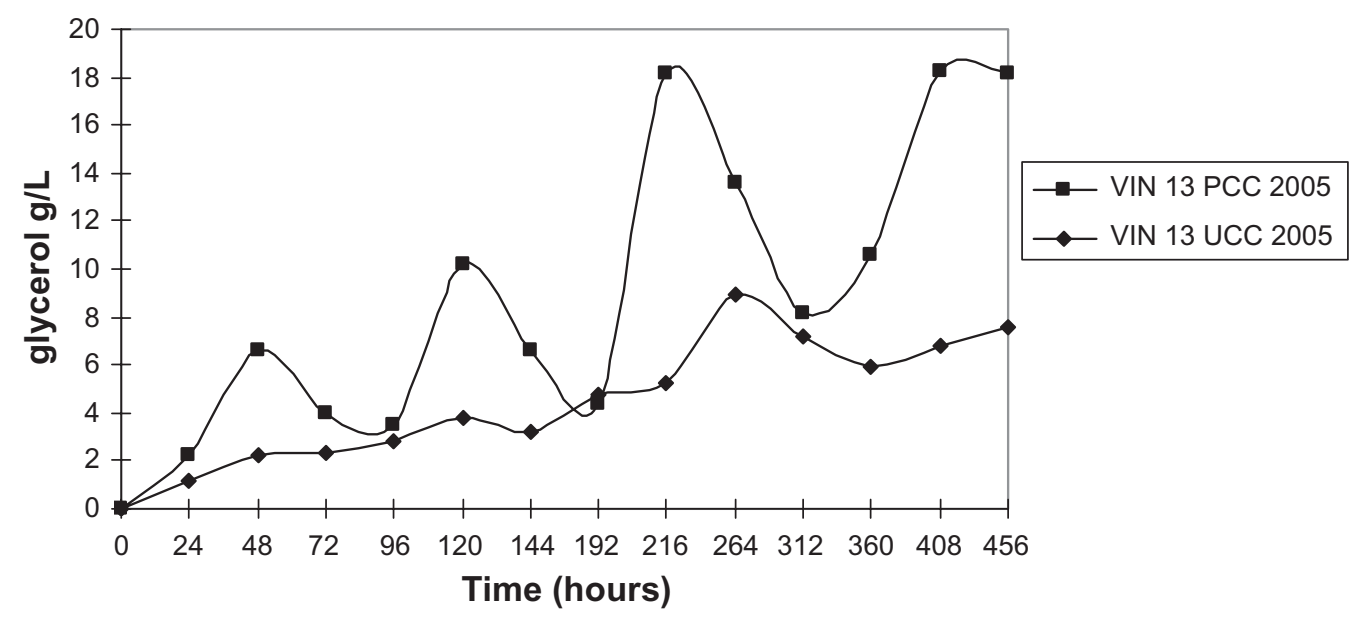

Figure 6 Glycerol production by salt-preconditioned and unconditioned wine yeast during fermentation of 2005 Chardonnay must. Standard error was I.62. Fermentations were conducted with preconditioned and unconditioned yeasts (strain VIN I3, Anchor Ltd, Capetown, South Africa) using $6 \%$ NaCl and growing cells for 24 hours prior to inoculation of $5000 \mathrm{~L}$ stainless steel tanks containing Chardonnay must. Must was clarified by pectynolitic enzymes and filtered before inoculation.

Both the fermentation ability and the sugar consumption appeared unaffected and during the first 24 hours sugar consumption was at its highest (Figure 4) - contradiction. Even the low pH (3.23) had little effect on both the fermentability and ethanol productivity. The total sugar concentration at the end of fermentation was low with concomitantly high alcohol levels. This indicates that preconditioned yeast cells had acquired an increased alcohol tolerance and ethanol production capability. Additionally, yeasts displayed: enhanced tolerance to high sugar concentrations, better adaptation to low $\mathrm{pH}$ levels and increased sugar consumption (especially for the first 24 hours of fermentation).

In summary, industrial scale fermentation experiments have revealed that osmotic prestress due to $\mathrm{NaCl}$ preconditioning enabled yeast cells to ferment sugars at high concentrations and produced high yields of alcohol. We hypothesize that the likely mechanism for this phenomenon lies at the level of elevated stress gene expression, especially linked to increases in the intracellular concentration of stresstolerance metabolites such as glycerol and trehalose.

\section{Disclosure}

The authors report no conflicts of interest in this work.

\section{References}

1. Attfield PV, Bell PJL. Genetics and classical genetic manipulations of industrial yeasts. In: Winde JH, editor. Functional Genomics of Industrial Yeasts. Berlin: Springer-Verlag; 2003.

2. Lambrechts MG, Pretorius IS. Yeast and its importance to wine aromaa review. S Afr J Enol Vitic. 2000;21:97-129.

3. Piskur J, Langkjaer RB. Yeast genome sequencing: the power of comparative genomics. Mol Microbiol. 2004;55(2):381-389.
4. Cavazza A, Versini G, DallaSerra A, Romano F. Characterization of six Saccharomyces cerevisiae strains on the basis of their volatile compounds production, as found in wines of different aroma profiles. Yeast. 1989;5:163-167.

5. Grando MS, Versini G, Nicolini G, Mattivi F. Selective use of wine yeast strains having different volatile phenols production. Vitis. 1993; 32:43-50.

6. Hohmann S. Osmotic stress signaling and osmoadaptation in yeasts. Microbiol Mol Biol R. 2002;66(2):300-372.

7. Hohmann S, Mager WH, eds. The osmotic stress response of Saccahromyces cerevisiae. In: Yeast Stress Responses. Berlin: Springer; 2003: 133-162.

8. Erasmus DJ. Genome-wide expression analyses: metabolic adaptation of Saccharomyces cerevisiae to high sugar stress. FEMS Yeast Res. 2003;3:375-399.

9. Logothetis S, Walker G, Nerantzis E. Effect of salt hyperosmotic stress on yeast cell viability. Proc Nat Sci Matica Srpska Novi Sad. 2007; 113:271-284

10. Logothetis S. Influence of sodium chloride on wine yeast physiology and fermentation performance. $\mathrm{PhD}$ thesis. 2009.

11. Lee SS, Robinson FM, Wang HY. Rapid determination of yeast viability. Biotechnol Bioeng Symp. 1981;11:641-649.

12. Miller GL. Use of dinitrosalicylic acid reagent for determination of reducing sugar. Anal Chem. 1959;31:426-428.

13. Rodríguez-Navarro A, Ortega MD. The mechanism of sodium efflux in yeast. FEBS Lett. 1982;138(2):205-208.

14. Fuping L, Yu Wang, Dongqing B, Lianxiang Du. Adaptive response of Saccharomyces cerevisiae to hyperosmotic and oxidative stress. Process Biochem. 2003;40(11):3614-3618.

15. Norberg J, Blomberg A. Metabolic and regulatory changes associated with growth of Saccharomyces cerevisiae in $1.4 \mathrm{~m} \mathrm{NaCl}$ : Evidence of osmotic induction of glycerol dissimilation via the dihydroxyacetone pathway. J Biol Chem. 1997;272:5544-5554.

16. Oda Y, Tonomura K. Sodium chloride enhances the potential leavening ability of yeast in dough. Food Microbiol. 1993;10(3):249-254

17. Morris GJ, Winters L, Coulson GE, Clarke KJ. Effect of osmotic stress on the ultrastructure and viability of the yeast Saccharomyces cerevisiae. J Gen Microbiol. 1986;129:2023-2034.

18. García MR, Ríos G, Ali R, Bellés JM, Serrano R. Comparative physiology of salt tolerance in Candida tropicalis and Saccharomyces cerevisiae. Microbiology. 1997;143:1125-1131.

19. Burg MB, Dmitrieva NI, Michea LF, Rocha GM. Cell cycle delay and apoptosis in response to osmotic stress. Comp Biochem Physiol A Mol Integr Physiol. 2001;130(3):411-420. 
20. Varela JCS, Vanbeekvelt C, Planta RJ, Mager WH. Osmostress-induced changes in yeast genes expression. Mol Microbiol. 1992;6:2183-2190.

21. El-Samargy YA, Zall RR. The influence of sodium chloride on the activity of yeast in the production of single cell protein in whey permeate. J Dairy Sci. 1988;71(5):1135-1140.

22. Speakman HB, Gee AH, Luck JM. The influence of sodium chloride on the growth and metabolism of yeast. J Bacteriol. 1928;15(5):319-340.

23. Soveral G, Madeira A, Loureiro-Dias MC, Moura FT. Water transport in intact yeast cells assessed by fluorescence self quenching. Appl Environ Microbiol. 2007;10:1-12.

24. Shimizu H, Hirasawa T, Ashitani K, et al. Comparison of transcriptional responses to osmotic stress induced by $\mathrm{NaCl}$ and sorbitol additions in Saccharomyces cerevisiae using DNA microarray. J Biosci Bioeng. 2006;102(6):568-571.
25. Wojda I, Alonso-Monge R, Bebelman JP, Mager W, Siderius M. Response to high osmotic conditions and elevated temperature in Saccharomyces cerevisiae is controlled by intracellular glycerol and involves coordinate activity of MAP kinase pathways. Microbiology. 2003;149:1193-1204.

26. Swiecilo A, Krawiec Z, Wawryn J, Bartosz G, Bilinski T. Effect of stress on the life span of the yeast Saccharomyces cerevisiae. Acta Biochim Pol. 2000;47(2):355-364.

27. Beney L, de Marañón IM, Marechal P, Moundanga S, Gervais P. Osmotic destruction of Saccharomyces cerevisiae is not related to a high water flow rate across the membrane. Biochem Eng J. 2001; 9(3):205-210.

\section{Publish your work in this journal}

The International Journal of Wine Research is an international, peer-reviewed open-access, online journal focusing on all scientific aspects of wine, including: vine growing; wine elaboration; human interaction with wine; and health aspects of wine. The journal provides an open access platform for the reporting of evidence based studies on these topics. The manuscript management system is completely online and includes a very quick and fair peer-review system, which is all easy to use. Visit http://www.dovepress.com/testimonials.php to read real quotes from some of our published authors. 